\title{
Q.
QNEEN'S
UNIVERSITY
BELFAST
}

\section{'Blessed are the young, for they shall inherit the national debt': Solidarity between generations in the Irish crisis}

Carney, G. M., Scharf, T., Timonen, V., \& Conlon, C. (2014). 'Blessed are the young, for they shall inherit the national debt': Solidarity between generations in the Irish crisis. Critical Social Policy, 34(3), 312-332. https://doi.org/10.1177/0261018313515972

\section{Published in:}

Critical Social Policy

\section{Document Version:}

Peer reviewed version

Queen's University Belfast - Research Portal:

Link to publication record in Queen's University Belfast Research Portal

Publisher rights

Copyright 2014 The Authors. This work is made available online in accordance with the publisher's policies. Please refer to any applicable terms of use of the publisher.

\section{General rights}

Copyright for the publications made accessible via the Queen's University Belfast Research Portal is retained by the author(s) and / or other copyright owners and it is a condition of accessing these publications that users recognise and abide by the legal requirements associated with these rights.

Take down policy

The Research Portal is Queen's institutional repository that provides access to Queen's research output. Every effort has been made to ensure that content in the Research Portal does not infringe any person's rights, or applicable UK laws. If you discover content in the Research Portal that you believe breaches copyright or violates any law, please contact openaccess@qub.ac.uk. 
'Blessed are the young, for they shall inherit the national debt':

Solidarity between Generations in the Irish Crisis

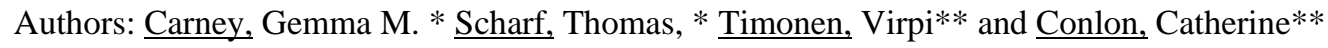

Critical Social Policy, 34, 2014, p312 - 332

*Irish Centre for Social Gerontology, National University of Ireland Galway, Ireland

**Social Policy and Ageing Research Centre, Trinity College Dublin, Ireland

\section{Corresponding author:}

Dr. Gemma M. Carney

Research Fellow

Irish Centre for Social Gerontology

National University of Ireland Galway

Galway

Ireland

E-mail gemma.carney@nuigalway.ie

Tel +35391495461 


\title{
'Blessed are the young, for they shall inherit the national debt': \\ Solidarity between Generations in the Irish Crisis
}

\begin{abstract}
Ireland has gained a reputation for peaceable acceptance of austerity following a European Union/International Monetary Fund bailout in 2010. While proponents of austerity praise Ireland's stoicism, critics of global capitalism argue that individuals and families are paying for mistakes made by elites. However, little is known about the strategies people adopt to cope with cutbacks to welfare entitlements. Drawing on a study of solidarity between generations living in Ireland in 2011-12, this article explores the lived experience of economic crisis and austerity. One hundred interviews with people of all ages and socio-economic backgrounds are analysed using constructivist grounded theory. Data show how austerity impacts differentially according to socio-economic status. While solidarity between generations leads to re-distribution of resources within families, providing some security for people with access to family resources, it reinforces inequality at societal level. We conclude that reliance on family promotes ‘coping' rather than 'protesting' responses to austerity.
\end{abstract}

Keywords: austerity, family, globalisation, grounded theory, Ireland.

\section{Introduction}

Economists have drawn parallels between the global economic crisis of the early twenty-first century and the Great Depression of the 1930s (Eichengreen and O’Rourke, 2012), referring to the distribution of debt between generations. It might not be possible to predict the future impact of the current economic crisis and the austerity programme in Europe, but the extent of personal and state-level indebtedness has caused many to argue that the youngest and future generations carry the heaviest burden. The scale of Ireland's debt problem calls to mind US President Herbert Hoover’s (1936) Great Depression era comment: 'blessed are the young, for they shall inherit the national debt.' This fear of long-term indebtedness may underlie the motivation behind the use of chronological age as a justification for redistributing resources between groups via social expenditure cutbacks (Beasley and O’Brien, 2013; Collins, 2012). In the Republic of Ireland, official statistics reveal that the austerity programme has resulted in high unemployment, increased emigration and rising levels of inequality and deprivation (Central Statistics Office, 2011). Some reports have singled out 'the under 45s' as suffering most in the recession (Gerlach-Kristen, 2013). In a this journal, Allen (2012: 422) used documentary evidence to show how Ireland's elite has adopted 'an intensified neoliberal response to the crisis' through implementing cuts to social welfare payments and wages. In presenting the findings of empirical research on the lived experience of austerity, the study reported here complements Allen's critical perspective on 
elite collusion in Ireland's crisis. Drawing on an analysis of solidarity between generations living in Ireland in 2011-12, this article marshals empirical evidence to substantiate Allen's (2012: 436) argument that by the time the austerity programme has been fully implemented, the Irish 'population will have made huge sacrifices to gain the prize for the model pupil of the IMF and EU.'

Arguments presented in this article are based on findings from [Study name] - a research project exploring solidarity between generations in Ireland. How people think about and practice solidarity towards other generations in their daily lives helps us to understand more about public support for the (re)distribution of resources between age (and other) groups, through tax and welfare transfers. The article begins by outlining why solidarity matters in the context of the economic crisis and the austerity programme in Ireland and Europe. It goes on to critically assess the idea of a debt between generations. It contextualises the [Study name] study with reference to Ireland's position in the broader global political economy. We then present the study design and methods. The remainder of the article draws on the dataset of 100 in-depth interviews to identify key features of the lived experience of austerity within families. The article concludes with reflections on the implications of intra-family solidarity for mitigating social risks under austerity.

\section{Solidarity in the context of economic crisis and austerity}

Early twenty-first century societies appear to display little solidarity and abundant individualism in social, economic and political life. There are a variety of means of describing the individualisation of society under capitalist regimes. Here we refer to three, namely the 'risk society', the 'winner-take-all society' and the use of credit to encourage consumerism.

Leading sociologists, such as Beck, have argued that societies have become more affluent but less secure. In Beck's (1992) 'risk society', individuals have more material resources but are less secure in their personal lives (due, for example, to changing family structures) and in their working life (arising, for example, from the demise of the job-for-life). Scholars of political economy, such as Hacker and Pierson (2010), identify Ireland as one of a group of unequal 'winner-take-all' societies where high levels of income inequality persist despite political equality. One major advance in explaining the growing exposure of individuals to risk has been made by Rajan (2010). In Fault Lines, he argues that fundamental inconsistencies emerge from the inter-relationship between democracy and capitalism in modern societies. As democratically elected politicians need votes to be re-elected, they are often unwilling to make the electorally unpopular changes necessary to tackle economic inequality. Instead, in capitalist systems, the availability of cheap credit allows elected representatives to perpetuate the myth that capitalism makes everyone rich. Rajan (2010) argues that this myth was a key fault line leading to the financial collapse of 2008, and that it will continue to cause credit crises if rising levels of inequality are not tackled by political means.

For the purposes of this article, we concentrate on one country implicated in the Eurozone crisis, the Republic of Ireland. In Ireland, the fallout from the credit crisis is a harsh and protracted programme of 
austerity, presented as a necessary ('there are no alternatives') retraction in response to over-expansion of global capital markets (Allen, 2012). Less clear are the consequences of these measures for the general population of affected countries. Levitas (2012: 322) emphasises the need for debate on the politics of austerity, drawing attention to how rising inequality, fuelled by austerity, is used to justify the 'progressive destruction of our collective provision against risk...and the increasing concentration of wealth and power in the hands of.... a feral elite'. More alarming still is Levitas's (2012: 326) remark that the lack of opposition to cuts is as worrying as the cuts themselves. The evidence leads Levitas (2012) to the conclusion that it is time to stop mourning and to start organising (p. 339).

Such different social science and policy perspectives suggest that in the race to 'develop', capitalist societies have become more unequal, less unified, more individualistic and less politically organised. If we are to understand the messy reality of austerity's human impacts, we must analyse the impact of crisis and austerity on individuals and families as well as on political economies. This article seeks to investigate the lived experience of solidarity during a time of crisis. As our study was concerned with solidarity between generations in the Irish economic crisis, we begin with a critical exploration of the concept of generation and of debt between generations.

\section{Debt between Generations}

While policy-makers and governments use austerity to meet European fiscal targets, media and public debate (for the most part) seem to collude in this policy by presenting austerity as the only solution to the crisis of capitalism. The fact that the level of debt distinguishes this economic crisis from previous downturns has led to some debates where the crisis is framed in generational terms, on the basis that 'elders make the decisions and the young make the sacrifices' (Moody, 2007: 131). In countries with high levels of youth unemployment, such as Italy and Spain, media headlines suggest that joblessness and emigration are leading to a fracturing of the social contract between age groups (for instance, 'Italy's lost generation: crisis forces young Italians to move abroad', Der Spiegel, 6 August 2012). Overt manifestations of the argument that the young are losing out at the expense of older generations are evident in conservative polemics, such as Willetts's (2010) The Pinch: how the baby boomers took their children's future - and how they can give it back. The idea that older generations have an ethical responsibility towards younger, and future generations is not new: 'We know that we cannot ignore them [future generations], that they are dependent on us...in trying to discharge our obligations toward them, we are doing no more than our parents did for us’ (Callahan, cited in Partridge, 1981: 84-5).

However, outside of kinship networks, the concept of generation cannot be used with analytic ease (Mannheim, 1993; Binstock, 2010). In his foundational contribution to the literature on family generations, Bengtson (1983: 48) identified generation as an important means of linking key events to social change throughout history: 'The concept of generation thus serves as the crucial link between time and social structure and is important in understanding the progress of historical events and the course of social change.' In this article we are interested in the impact of the economic crisis of the early twentyfirst century and the subsequent austerity programme on all generations living in Ireland. In particular, 
we use this opportunity to investigate what (if any) role solidarity between generations may play in dealing with economic distress. Given the analytical imprecision of 'generation' as a concept, we use the proxies of age and life stage to get closer to a meaningful comparison of how people at different stages of the life course experience the austerity programme (see Table 1). The article engages with generational relations as a mechanism for re-distributing resources between family generations. We now provide some context to Ireland's current predicament.

\section{Ireland: Small and Exposed in the Global Political Economy}

From 1994, Ireland, a peripheral country of 4.6 million inhabitants on the western edge of Europe, came to be seen as a success story of the expansion of global capitalism via European economic cooperation (Murphy, 2000). Ireland joined the European Economic Community in 1973 and the Eurozone in 2000, enjoying considerable increases in prosperity over that period. Economic growth increased from an average of 3.9 per cent per annum between 1960 and 1980 to an average of 7.1 per cent between 1993 and 2000 (Kennedy, 2001). Globalisation, in particular Ireland's successful campaign to attract US-based multi-national corporations (such as Dell, IBM, INTEL and Google), has been credited with this growth. Globalisation allowed Ireland to capitalise on its strategic geographic position between 'two economic tectonic plates' - the United States and the European Union (Murphy, 2000). Ireland's seeming success was also partly attributed to low corporation tax; a compliant labour force, thanks to pay agreements achieved through a corporatist system of 'social partnership' (1987-2010); and the in-migration of workers from Eastern Europe, parts of East Asia and Africa. The combination of US-style capitalist increase and European-style consensus politics led to economic growth and fluctuating levels of income inequality. Comparatively, Ireland occupies an unusual position in terms of the 'new economic geography' of globalisation, and is viewed as 'an outlier among rich European nations in terms of its high degree of income inequality, but still falling well short of the level seen in the United States' (Nolan et al., 2005: 539).

There are important political aspects to this boom period, commonly labelled the Celtic Tiger era (19942007). Giveaway budgets characterised the leadership of Bertie Ahern who served as Taoiseach (Prime Minister) from 1997 to 2007. Ahern's governments chose to cut taxes, invest in infrastructure through public-private partnerships and increase welfare payments. Ahern's Fianna Fáil party won elections in 1997, 2002 and 2007 on the basis of its putative capacity to produce economic growth, and Ahern's personal popularity. Meanwhile, consumer prices, particularly property prices, rose exponentially, with Ireland leading the Organisation for Cooperation and Economic Development (OECD) property price growth index between 1995 and 2007 (McCarthy and McQuinn, 2011). Electoral and economic cycles became engaged in a self-fulfilling prophecy: increased wealth led to increased popularity, which in turn led to increased spending (Rajan, 2010).

Ireland, now strategically positioned as a small open economy between the titans of western capitalism, the United States and the European Union, quickly suffered the negative effects of the US banking crisis that started in 2008. Severe and sudden recession caused the Irish government to jettison consensus 
politics, making a number of unilateral decisions, including a bank guarantee which has made people living in Ireland responsible for the country's massive bank debt. Emigration, the traditional pressure valve for rising unemployment in Ireland, increased exponentially from a low of 25,600 out-migrants in 2002 to 87,100 in 2012 (Central Statistics Office, 2012). In the 2011 general election, voters evicted Fianna Fáil, the party of the boom period, from office. The new coalition government (led by the Fine Gael party) promised clean government and a direct connection with the reality of ordinary people's lives. By the time the 2011 election was held, the country had already accepted the first European Union/International Monetary Fund bailout. The stringent terms of the bailout were ratified by the electorate in a referendum by a large majority, with 60.3 per cent voting in favour in 2012. By October 2012, Ireland's new Taoiseach, Enda Kenny, was lauded on the cover of TIME magazine for staging a 'Celtic Comeback'. The fact that people living in Ireland have peaceably accepted budget cuts, while similar measures have seen violent protest on the streets of Spain and Greece, is identified as a major asset in Kenny's mission to return Ireland to the global markets (Meyer, 2012).

It is under the shadow of these challenging economic circumstances that the [Study name] study began to interview people living in Ireland. Researchers invited people to speak on the subject of the distribution of resources within families and between different groups in society.

\section{Method: Constructing Grounded Theory}

The grounded theory approach is ideally suited to studying poorly understood phenomena (Glaser and Strauss, 1967; Charmaz, 2006). It entails transparency and openness in reporting research methods to show how data were collected and to demonstrate the empirical basis for the resulting theory. Grounded theory construction involves a number of iterative processes, including but not limited to: simultaneous data collection and analysis; pursuing emergent themes through early data analysis; discovering basic social processes within data; inductive construction of abstract categories to explain and synthesise these processes; sampling to refine categories; and integrating categories into a theoretical framework (Charmaz and Belgrave, 2012: 348).

Given the analytical imprecision of 'generation' as a concept, we opted to use two proxies which come closer to a meaningful comparison of how people at different stages of the life course experience the austerity programme. We sampled for age (see Table 1 and explanation) and framed our interview questions not in terms of generation, but as 'life stages'. This allowed us to design an interview schedule that invited participants to talk about their personal lives and perspectives on solidarity in Ireland more generally. The concept of solidarity was never used explicitly (because it is 'loaded' and inaccessible to some groups), but was applied in concrete terms as (perceptions of the fairness of) the distribution of resources between different (age) groups in Ireland. The central research question was: 'How do people in Ireland perceive the distribution of resources across age groups?'

An interview guide of ten questions was developed. Two introductory questions allowed participants to locate themselves in relation to the study ('tell me about the stage you are at in your life now?' and 'who 
would you say are the people closest to you?'). Four further questions were intended to tap into 'give' and 'take' at family, community and societal levels:

- $\quad$ Can you tell me about the help and support, if any, you are receiving from other people at the moment? [receiving - individual/family]

- $\quad$ Can you also tell me about any help and support you are giving to others at the moment? [giving - individual/family]

- $\quad$ Thinking about Ireland as a whole, in what ways do you think that you are contributing to Irish society? [giving - community/political economy]

- What do you see yourself receiving from the State? [receiving - community/political economy]

The study gained ethical approval in July 2011. Between September 2011 and July 2012, three members of the research team conducted 100 in-depth semi-structured interviews with men and women aged between 18 and 102 years and across three broad socio-economic categories (derived on the basis of occupational classification by Ireland's Central Statistics Office). Each interview was audio-recorded and transcribed verbatim. Sampling and recruitment aimed to maximise diversity across age, gender and socio-economic status, and was also guided by theoretical sampling principles (Charmaz, 2006). Theoretical sampling occurs after the initial data collection and analysis. The process entails developing tentative categories from data then sampling to strive for discovery of variation in the category and differences between categories (Charmaz, 2006). Several different community-based sampling strategies were used. Harder-to-reach populations, such as homeless people, immigrants and members of Ireland's Traveller community, were also recruited. Given the dominance of family in we also sought out socially isolated individuals.

Table 1 summarises the sample composition by gender, age group and socio-economic status (SES). SES is defined according to definitions used by Ireland's Central Statistics Office.1 The final sample emerged in line with our efforts to maximise heterogeneity. Theoretical sampling early in the data collection suggested that SES is significant in shaping experiences and perceptions of solidarity, hence the decision to recruit a relatively evenly balanced sample across the three SES groups and four age bands (18-25, 26-50, 51-74 and 75+ years).

\section{[Table 1 about here]}

Interview data were analysed following constructivist grounded theory building (Charmaz, and Belgrave, 2012). Regular meetings of the authors were used to discuss questions arising from the data, directions 
of analysis and coding. Insights from across the dataset were pooled and then debated for contrast and overlap.

\section{Findings}

Our analysis addresses how different (age and socio-economic) groups experience austerity. We find marked differences between each group's perception of the crisis and the possible impact of the austerity programme. For illustrative purposes, we are confining our focus to thirteen participants. These individuals offer insights relevant to the emerging theory that, in Ireland, austerity generates responses from family that buffer the impacts of the recession. For this reason we include some details of each participant's family status in Table 2. The views and experiences of participants living at opposite ends of continua that shape the analysis (for example, Matt Coyne, aged 70, high SES and high family solidarity versus Charlie Connolly, aged 20, low SES and low family solidarity) help us to construct knowledge about how the experience of crisis and austerity has different impacts for individuals depending on their age, socio-economic status (including employment/welfare status) and level of family solidarity. Inferences drawn from the 13 selected cases reveal tensions and contradictions that bring us closer not only to understanding differential experiences of living through austerity, but also addressing the loss of trust in institutions other than the family that appears to result from the austerity programme. Those included in the analysis are predominantly from lower SES backgrounds for two reasons. First, as the analysis draws on interviews with theoretically useful insights on the lived experience of austerity, the most illuminating depictions of poverty, not surprisingly, emerged from interviews with the poorest people in our sample. Second, those included are predominantly on publicly funded benefits, which, since the first austerity budget in 2008, have been targets for government budget cuts (Allen, 2012).

\section{Young Adults (aged 18-25 years)}

Younger people at the bottom of the socio-economic pyramid, whose parents have not had the resources to invest in their education and personal development, are most pessimistic about the future. At the age of 20, Charlie is still struggling to pass secondary school exams in a special youth programme. He considers his friends to be 'the family I choose'. He struggles with basic skills of daily living, and in dealing with authority. He makes a few vague references to long-term goals, such as going abroad, but has no concrete future plans. Life is a constant struggle from week to week. However, he has managed to reduce his drinking, and is not taking drugs. By the measure of peers within his social network, this amounts to success. Charlie's experience is echoed in interviews with other young men in the lowest SES category, such as Raymond Kelly.

Charlie and Raymond describe 'epiphany moments' when they began to realise that they were becoming disengaged from society. Raymond offers graphic descriptions of how State services, including detention centres, had failed him. These young men's experiences demonstrate how, in a society where security is provided primarily from private, family resources, being born into a poor family allows disadvantage to 
be passed on from one generation to the next. Relative to those in high SES categories, this group has been hardest hit. In six austerity budgets in a four-year period, government has tended to cut social welfare and expenditure on public services, rather than increase taxes. Stacey Mullins, an unemployed 19-year old who grew up in a one-parent family, critiques political elites for making cuts in the full knowledge that the most vulnerable will be left worse off. She makes an impassioned call for a just society:

'I would love to put them - bankers and Government people - in a council house as a lone parent with three kids. Just give them three kids for a week...I tell you the country would be changed so much.'

In sharp contrast, Luke Farrell, an 18-year-old whose parents' occupations put him in the high SES category, is about to take his secondary school exams and brims with self-efficacy. Luke believes he will succeed. Throughout the interview, he associates his position, opportunities and imagined trajectory with his own capacity. In his view, it is particularly his strong internal motivation, reliability and, most of all, his intellect that leave him well-positioned to succeed. Luke has an individualistic orientation which he likens to Dickensian England:

Luke: I sort of dream big. What I would say is only 'do your best', because otherwise what is the point? My upbringing is similar to Great Expectations and that sort of thing. You know the Charles Dickens book Great Expectations?

Interviewer: Can you elaborate on what you mean?

Luke: You sort of want to get there. You want to get the best you can for yourself and for everyone else.

Few of the people in the youngest age group have started to make concrete plans for their future beyond one or two years. Many are still living at home, financially dependent on parents or enrolled in youth programmes. Unlike those aged 26-50, people in this group are unlikely to have mortgage debt or childcare responsibilities. They have immediate concerns, but apart from expressions of contempt towards corrupt business people, over-paid civil servants and politicians, they did not appear to have reflected in-depth on the causes of and solutions to the crisis.

\section{Adults (aged 26-50 years)}

Joblessness and insecurity means that emigration is to the forefront of the minds of many people from this age group. Several participants refer to emigration as a 'rite of passage for the Irish' (Gary Hogan, 36, low SES). For some, family is the main reason why they choose to stay in Ireland. Glen Giddens (45, low SES), who moved to Ireland from the UK some years ago, compares the low level of unrest in Ireland with youth riots in England in 2011. He expresses surprise that there has been no unrest: 
'I mean it's really hard...for the kids...their opportunities are vanishing. I'm surprised they haven't been rioting the way they did in the UK - that was sparked off by the feeling that there is nothing there...I suppose in this country people emigrate and that's what stops it from overboiling.'

Rosalind Keeling (28, low SES), a student who had previously been deeply involved in a high-profile anti-capitalism protest movement, offers credence to Glen's idea that emigration exports Ireland's youth unemployment problem. When asked about her expectation of receiving from the State in the future, Rosalind sees no future in Ireland:

'I would be gearing up for leaving Ireland, so I don't expect to be keeping my contract with the State and I don't expect to be paying any tax back to them either when I do eventually start working. I think they are realising that now as a lot of people are leaving...Most people are going to Australia, aren't they?'

Rosalind sees her disillusionment with the State as typical. Like many other Irish people she intends to vote with her feet and leave the country.

People from the middle-income groups, who invested in Ireland's failed property market, feel decisionmakers are increasingly out of touch with the day-to-day experience of living with austerity. For many, it is not only the drop in income (through pay cuts or job loss), but the constant threat of further cuts to public services and social welfare payments which heightens feelings of insecurity. Majella Carey (32, middle SES), a public sector worker, considers that she was made two promises by previous governments, both of which were broken. She was sold a house on an affordable housing scheme. That mortgage is now in negative equity, and the scheme, which obliges her to return 60 per cent of the profit of a sale back to the State, will not take 60 per cent of the $€ 48,000$ loss she carries. The salary of her public sector job has diminished by €8,000 per annum because of government levies imposed as part of the austerity programme. Majella expresses a muted anger shared by many participants from similar socio-economic categories and life stage:

'I try to be law abiding, and I think sometimes you just get no thanks for that...Do I feel I was sold something twice now by government and it is gone pear-shaped? You know, the house being the first and the job being the second? It's like they reel you in and then they just take the lifejacket off you and throw you into 10 feet of water.'

The feeling of being abandoned by government when the economic crisis struck is shared by Gary Hogan, aged 36 years and of low SES, who experienced downward social mobility when a workplace accident left him unable to continue to work as a skilled tradesman. Gary felt the State did not value him once he could not work: 
'You're not valued...This happens right across the construction sector, lots and lots of men have got this, they worked for so long, paid so much in tax, and when they go back to the system they are told "No. Your wife is working. You're not entitled to anything!"”

\section{Older Adults (aged 51-74 years)}

Matt Coyne (70, high SES) is concerned with how budget cuts seem to be aimed at the weakest in society. He feels his generation should make more of an economic contribution through higher taxes. When the interviewer referred to survey research evidence that older people tend to transfer material resources downwards, asking 'Do you do that?', Matt disclosed that this also reflects his situation:

'Oh, I do. That's where a lot of my disposable income is going. I have an unemployed son who has a family and I have a daughter that I had to support. It's my pleasure and my privilege to help my children, but I worry about my son because he has a family.'

Matt is offering security to his adult children (and grandchildren) through the informal transfer of resources down the family generations. Yet, as a former banker, he is aware that his experience of paying mortgages for two generations represents a significant contortion of the ideal of financial independence through capitalist wealth accumulation. Like many people who invested in Ireland's property bubble, Matt feels somehow implicated in the economic crisis. With a heavy note of irony, he asks: 'Are we going to talk about mortgages going on for two generations? Maybe that's the solution?' Matt is not the only participant in the 51-74 age group engaged in insulating younger family generations from catastrophic costs incurred by the debt crisis. Despite the fact that Matt's savings, carefully accumulated for his and his wife's old age, are dwindling as a result of transfers to his adult children, Matt is happy with his life:

'I'm very happy. I'm very fortunate! As long as I have my good wife spared to me [i.e. alive] and I can keep doing something for my son until he gets on his feet.'

Regardless of socio-economic status, participants aged between 51 and 74 years who have adult children are actively involved in providing varying forms of help and support to other generations. For instance, Eilis Lynott (57, low SES) survives on a very low income. She is so busy providing free childcare for her daughter's children and eldercare for her mother that she cannot work outside the home. Her response to the first question 'can you tell me about your life stage now?' is indicative of where Eilis's priorities lie:

'Well I'm 57, divorced, look after my grandchildren, look after my Mum, not full-time with my Mum because she lives with my brother, but I feel that I do. I have to take care of her and get her pension, do you know, wash the floors and, you know, things you'd do for her.' 
Eilis also provides a free after-school service for her older grandchildren. When the interviewer later remarks that she is very generous in caring for and feeding her grandchildren on a daily basis, she shrugs it off as her taken-for-granted duty: 'I just take all that as, they are my grandkids, you know, you just feed them...'

\section{The Oldest Old (aged 75 years and over)}

Patricia Kilburn (90, low SES), a returned emigrant, is not alarmed by the austerity programme. When asked about distribution of resources between generations, she describes how difficult it is for today's young people to comprehend the poverty of her own youth. Patricia left Ireland in 1936, when she was 14. Her parents, raising eight children on the west coast of Ireland, could not afford to feed her or her siblings and consequently sent their young teenage children to Scotland to work as farm labourers:

'Even your generation would not survive one week the way that we had to out in potato fields in Scotland at 13 and 14 years old. All the water coming down and you picking potatoes and your mum or your sister or whoever would be with you... That would be at three or four o'clock in the morning. But when you're young you don't think on that kind of thing. So the children, nowadays, has [sic] got a good life in comparison to my time.’

For Patricia, whose experience was of absolute poverty and forced emigration, there seems to be no need to complain about poverty in the Ireland of 2012.

For entirely different reasons, Sylvia White, an 83-year-old woman from a family that has enjoyed generations of wealth, sees little to complain about. Sylvia believes that finding oneself hungry in Ireland in 2012 is down to bad management'. She is, however, critical of the super-rich: 'I don't know what they want with $€ 280 \mathrm{~m}$ [names two disgraced heads of failed Irish banks who amassed huge personal wealth]. Like is it greed...why?' Sylvia’s strongest solidarity is towards her family, and people like herself hardworking and self-sufficient, but not greedy.

When asked about changes over time, a number of people in this oldest age group did refer to removal of the Catholic hierarchy from positions of unaccountable power, particularly in relation to the care of young children, as a significant improvement for Ireland. Peggy, an 84-year-old woman from a rural area in the west of Ireland, remarks:

'One thing I notice nowadays that have improved greatly than when I was a child, we were afraid of the priests, not all of the priests, some of them were very nice but they were so strict. I mean the Mission Fathers would come and they would be hitting the crucifix against the altar and shouting about hell and damnation.’

Peggy goes on to offer graphic memories from the 1940s of how her father would sometimes help 'runaways' from the local 'reformatory school' (juvenile penal institution) to make good their escape. 
Like many of the oldest old, she uses the benefit of hindsight to conclude that it was those in power (clergy), not the people, who were the problem: 'when we look back now, they [clergy] were the ones that were doing all the trouble, with the children in [names reformatory school] and all that.'

\section{Discussion}

This article has sought to address a set of central concerns arising from our grounded theory study of solidarity between generations in the Irish economic crisis. It is framed as an investigation of the human impact of austerity, offering a qualitative, empirical contribution to the literature on economic crisis and austerity (Hacker and Pierson, 2010; Rajan, 2010; Allen, 2012). Drawing on 100 in-depth qualitative interviews, our analysis indicates that the outwardly peaceable response to austerity by people living in Ireland is due to a combination of factors. We use quadrants to consider different responses to austerity according to age and socio-economic status (Figure 1), using four participants described above as illustrative examples, each one an illustration of the reasons behind Ireland's 'model pupil' image in the context of austerity (Allen, 2012).

\section{[Figure 1 about here]}

\section{Surviving Day-to-Day (aged 18-25)}

Young adults from low socio-economic backgrounds (18-25, top left quadrant) suffer most. Growing up at the bottom of a 'winner-take-all' society (Hacker and Pierson, 2010), means that people like Charlie Connolly lack the education and resources to absorb the impact of the austerity programme. There are few opportunities for unskilled workers and our analysis suggests that being without family support puts young people at greater risk of being outside work. The experience of poverty and inequality means that young adults from low socio-economic backgrounds have more in common with low SES oldest people, than with young people in the high SES category. For instance, Luke Farrell (18) and Sylvia White (83) remain largely untouched by the austerity programme. This contrasts with Charlie Connolly (20) and Patricia Kilburn (90) who, through multiple generations of cumulative disadvantage, have little prospect of rising out of poverty.

\section{Planning to Emigrate (aged 26-50)}

Lower and mid-SES younger people like Majella Carey (aged 26-50, top right quadrant) keep emigration as a back-up plan. If the austerity measures become intolerable, taxes increase and unemployment rises, people in this category, particularly the better educated, will emigrate. Individuals in this group do not plan to maintain their contract with the Irish State in the longer term. The option to emigrate is permanantly there, having become an unofficial policy repeatedly used to survive hardships like colonialism, famine and numerous recessions. People who stay behind experience a fractured, temporary relationship between the State and citizen. The loser in 
this weakened social contract is the Irish State, which invests resources in educating children, effectively for export as young workers.

\section{Using Private Resources to Support Family (aged 51-74)}

High SES people like Matt Coyne (aged 51-74, bottom left quadrant) are involved in complex, multi-generational economic transfers arising from investments made during Ireland's property boom. Participants like Matt express a sense of being somehow responsible for the country's indebtedness through over-reliance on credit. Matt has maintained his high socio-economic status through the capitalistic belief that hard work and investment in private property will provide security. These beliefs have been shaken by the severity of the property crash. In the absence of alternatives, Matt continues to invest in his family's future, hoping to 'get through' until capitalism can start to work in their favour again. Across socio-economic categories, we find that for those in the 51-74 age category, the main focus is on helping adult children. Where adult children have lost jobs, parents make mortgage repayments. Where adult children are employed, the focus is on providing free care of grandchildren. The fact that the state pension is the only welfare payment that has not (yet) been cut allows pensioners to provide financial aid to younger family generations.

\section{Viewing Present as Favourable to Past (aged 75 and over)}

The oldest old in the sample (aged 75 and over, bottom right quadrant) have a unique perspective on the twenty-first century economic crisis and programme of austerity. Older people in the low SES group have witnessed massive improvements in material wealth in comparison with the Ireland of their childhoods. For some older participants, the length of their perspective on social change in Ireland renders the Celtic Tiger an insignificant phase. For instance, Patricia Kilburn has lived through many changes since Ireland began to modernise from the 1960s onwards. Out of line with the rest of its history, Ireland's brief period as an economic 'success story' was in Patricia's view one of blind ambition and unrealistic expectations. For the over-75s, the unquestioning support from family and community has sustained Irish people in the past and will see them through again. Many members of this group also refer to social change, such as the demise of the power of the Catholic Church over social service provision, as a major advancement for Ireland.

\section{The Role of Family Solidarity in the Irish Crisis}

Across all quadrants there is strong evidence that risk individualisation is mediated by family. Risks of poverty, ill health, and educational disadvantage are mitigated or exacerbated by one's family relationships. Matt Coyne’s son and daughter are insulated from income insecurity through their father's generosity, to the detriment of Matt's personal savings. Luke Farrell's advantaged start in life is the result of his parents' relative wealth and capacity to invest in his potential. Within our sample, it was common practice for older family members to provide financial support to younger people to off-set the catastrophic costs they are encountering from the global credit crisis. Conversely, many younger family members provide care for older relatives, either directly (care labour) or indirectly (payments towards care, organisation of care). In effect, despite an atomising programme of austerity, we find overwhelming evidence of intra-family solidarity in Ireland. Solidarity is experienced between family members as 'old' 
practices (such as dependence on closest kin for money and practical help) are resuscitated in response to Ireland's crisis. However, reliance on families, while helping people to survive the recession, is an engine of deep and sustained inequality.

\section{Conclusion}

This article has explored experiences of solidarity amongst people living through the Irish debt crisis. We draw two conclusions from our analysis. First, families absorb some of the impact of cuts, but family involvement in cushioning the impact of the crisis also brings into sharp relief the unequal capacities of families to cover for the social risks of their members. Second, reliance on family promotes 'coping' rather than 'protesting' responses to austerity. We identify four 'coping' responses to austerity (Figure 1). The youngest and poorest people living in Ireland are trying to survive. Younger people with higher education intend to exit through emigration. Pensioners with disposable income are transferring resources to younger family generations, adopting a ‘family will see us through' strategy. Finally, many of the oldest old compare the current crisis to multiple past crises, seeing no reason to protest. These 'coping' strategies may help to explain why there are few large-scale protests despite the fact that 'lower and middle income sectors of the population are carrying the main burden of paying for a banking crisis that was caused by a very small elite group’ (Allen, 2012: 433).

The lack of protest is remarkable given that our micro-level data corroborate Allen's (2012: 429) conclusions that austerity is depressing living standards, even for those at work. For the rising numbers of jobless people, social policy plays an important role, as cutting back of social welfare benefits makes it even more difficult for those on benefits to survive. The government mantra that 'everyone must pay' has disproportionately penalised people already vulnerable to deprivation, such as 'lone parents, the unemployed and short-time workers, the elderly and large families' (Allen, 2012: 432). Passivity is also the result of a successful strategy of legitimation by elites. Elites have presented Ireland's dual policy of low corporation tax and growth-driven development as a bet that did not come off, the outcome of which national leaders cannot change. By carrying forward Ireland's $€ 90$ billion debt burden (Allen, 2012: 426), elites claim to have averted widespread deprivation akin to the Great Depression. Placing the burden on future generations has allowed politicians to avoid the political disruption seen in other states hit by the credit crisis, such as Iceland. By letting old practices, such as family solidarity, mitigate the personal impact of austerity, the Irish government seems to be 'coping peaceably', appearing as a 'model pupil' (Allen, 2012).

We concur with Allen (2012) that such passivity may not last. Passivity of older generations will be eroded as some families' resources are depleted, and as new cohorts of the oldest old expect more from the State. The global nature of the recession may remove emigration as an exit strategy for younger generations. Given such increasingly harsh and unequal conditions of capitalism, people may begin to understand that intra-family redistribution is not enough, and must be accompanied by a more collectiveredistributive politics. Under these conditions, people living in Ireland might just stop coping and 'start organising' (Levitas, 2012: 339). 


\section{Note}

${ }^{1}$ SES categories represent a regrouping of seven social class groups as follows: 'High SES' comprises Group 1 Professional workers and Group 2 Managerial and technical; 'Middle SES' comprises Group 3 Non-manual and Group 4 Skilled manual; and 'Low SES' comprises Group 5 Semi-skilled, Group 6 Unskilled and Group 7 All others gainfully occupied and unknown.

\section{Acknowledgements}

The authors are grateful to the participants in the study and to The Atlantic Philanthropies for funding this research (grant number 20309). Gemma Carney wishes to thank colleagues at the Political Studies 
Association of Ireland, the Gerontological Society of America and Southampton University, especially

Professor Gerry Stoker, for providing comments on earlier presentations of the article. Thanks to Caroline Finn and Lara Wolkeimer for research assistance.

\section{References}

Allen K (2012) 'The Model Pupil who Faked the Test: Social Policy in the Irish Crisis’, Critical Social Policy 32(3): 422-439.

Beck U (1992) Risk Society: Towards a New Modernity. Thousand Oaks, CA: SAGE. 
Beesley A, and O'Brien D (2013) 'Under 45s hit "dramatically" harder by recession, ESRI finds', Irish

Times, 14 May 2013, downloaded 26 June 2013 at http://www.irishtimes.com/business/economy/under-45s-hit-dramatically-harder-by-recession-esrifinds-1.1392283

Bengtson VL, Furlong, MJ, and Laufer, RS (1983) 'Time, Aging, and the Continuity of Social Structure: Themes and Issues in Generational Analysis', Journal of Social Issues 39(4): 45--71.

Binstock RH (2010) 'From Compassionate Ageism to Intergenerational Solidarity', The Gerontologist 50(5): 574-585.

Central Statistics Office (2011) Survey on Income and Living Conditions. Dublin: Central Statistics Office.

Central Statistics Office (2012) 'Population and Migration Estimates' Dublin: Central Statistics Office.

Charmaz K (2006) Constructing Grounded Theory: A Practical Guide through Qualitative Analysis. London: SAGE.

Charmaz K and Belgrave L (2012) 'Qualitative Interviewing and Grounded Theory Analysis', pp. 347367 in JF Gubrium, JA Holstein, AB Marvasti, and KD McKinney (eds) Handbook of Interview Research: The Complexity of the Craft. Thousand Oaks, CA: SAGE.

Collins S (2012) 'Punishing the Young for the Sins of their Elders', Irish Times, 15 September 2012, downloaded 26 June 2013 at http://www.irishtimes.com/debate/punishing-the-young-for-the-sinsof-their-elders-1.531329.

Eichengreen B and O'Rourke K (2012) 'A Tale of Two Depressions Redux', downloaded 26 June 2013 at http://www.voxeu.org/article/tale-two-depressions-redux.

Ehler F (2012) 'Italy’s Lost Generation: Crisis Forces Young Italians to Move Abroad’, Der Speigel, 6 August 2012, downloaded 26 June 2013 at http://www.spiegel.de/international/europe/euro-crisisforces-many-italian-young-people-to-leave-a-848509.html.

Gerlach-Kristen P (2013) Younger and Older Households in the Crisis Dublin. Quarterly Economic Commentary, Spring 2013. Dublin: Economic and Social Research Institute.

Glaser B and Strauss A (1967) The Discovery of Grounded Theory. Chicago: Aldine.

Hacker JS and Pierson P (2010) 'Winner-Take-All Politics: Public Policy, Political Organization, and the Precipitous Rise of Top Incomes in the United States', Politics \& Society 38(2): 152-204.

Hoover H (1936) Address to the Nebraska Republican Conference, Lincoln, Nebraska, 16 January 1936.

Kennedy K (2001) 'Reflections on the Process of Irish Growth', Journal of the Statistical and Social Inquiry Society of Ireland, 32, pp. 123-139.

Levitas R (2012) 'The Just's Umbrella: Austerity and the Big Society in Coalition Policy and Beyond', Critical Social Policy 32(3): 320-342.

Moody, Harry R. 2007. "'Justice between generations: the recent history of an idea' " In Critical Perspectives on Ageing Societies, ed. M. and Scharf Bernard, T. . Bristol, UK: Policy Press.

Mannheim K (1993) 'The Problem of Generations', pp. 22-65 in MA Hardy (Ed.) Studying Aging and Social Change: Conceptual and Methodological Issues. London: SAGE.

McCarthy Y and McQuinn K (2011) 'Decomposing Irish House Price Movements: 2000-2010', presented at The Irish Mortgage Market in Context, 13 October 2011, downloaded 26 June 2013 at http://www.centralbank.ie. 
Moody HR (2007) 'Justice between generations: the recent history of an idea', pp.129-135 in M Bernard and T. Scharf (eds) Critical Perspectives on Ageing Societies. Bristol: The Policy Press.

Meyer C (2012) 'The Irish Answer’, Time, 15 October 2012.

Murphy A (2000) 'The 'Celtic Tiger' - an analysis of Ireland's economic growth performance', Robert Schuman Centre for Advanced Studies 2000/16. Downloaded 7 November 2012 at http://www.eui.eu/RSCAS/WP-Texts/00_16.pdf.

Nolan B and Smeeding TM (2005) 'Ireland’s Income Distribution in Comparative Perspective', Review of Income and Wealth 51(4): 537-560.

Partridge E (1981) Responsibilities for Future Generations. Buffalo, NY: Promentheus.

Rajan R (2010) Fault Lines: How Hidden Fractures Still Threaten the World Economy. Princeton: Princeton University Press. 
Table 1: Changing Generations sample profile by gender, age and socio-economic status ( $\mathrm{N}=100)$

\begin{tabular}{|c|c|c|c|c|c|c|c|c|c|}
\hline \multirow{2}{*}{$\begin{array}{l}\text { Socio-economic status } \\
\text { High }\end{array}$} & \multicolumn{4}{|c|}{ Men $(N=46)$} & \multicolumn{4}{|c|}{ Women $(N=54)$} & Totals \\
\hline & $18-25$ & $26-50$ & $51-74$ & $75+$ & $18-25$ & \multirow{2}{*}{$\begin{array}{c}26-50 \\
10\end{array}$} & \multicolumn{2}{|c|}{$51-74 \quad 75+$} & \multirow[b]{2}{*}{36} \\
\hline & 4 & 5 & 8 & 3 & 1 & & 3 & 2 & \\
\hline \multirow[t]{2}{*}{ Middle } & $18-25$ & $26-50$ & $51-74$ & $75+$ & $18-25$ & $26-50$ & $51-74$ & $75+$ & \multirow[b]{2}{*}{27} \\
\hline & 1 & 4 & 3 & 2 & 4 & 5 & 3 & 5 & \\
\hline \multirow[t]{2}{*}{ Low } & $18-25$ & $26-50$ & $51-74$ & $75+$ & $18-25$ & $26-50$ & $51-74$ & $75+$ & \multirow[b]{2}{*}{37} \\
\hline & 6 & 4 & 5 & 1 & 6 & 6 & 4 & 5 & \\
\hline TOTALS & 11 & 13 & 16 & 6 & 11 & 21 & 10 & 12 & 100 \\
\hline
\end{tabular}


Table 2: Characteristics of participants quoted

\begin{tabular}{|c|c|c|c|c|}
\hline Pseudonym & Age & $\begin{array}{l}\text { Socio- } \\
\text { economic } \\
\text { Status }\end{array}$ & $\begin{array}{l}\text { Employment/Welfare } \\
\text { Status }\end{array}$ & Experience of Family Solidarity \\
\hline $\begin{array}{l}\text { Luke } \\
\text { Farrell }\end{array}$ & 18 & High & Second Level Student & $\begin{array}{c}\text { Two married and well-resourced } \\
\text { parents who support his educational and } \\
\text { personal development }\end{array}$ \\
\hline $\begin{array}{l}\text { Stacey } \\
\text { Mullins }\end{array}$ & 19 & Low & $\begin{array}{l}\text { Unemployed (on } \\
\text { youth scheme) }\end{array}$ & $\begin{array}{l}\text { Lives with mother who is lone parent. } \\
\text { Cares for grandmother with dementia. }\end{array}$ \\
\hline $\begin{array}{l}\text { Charlie } \\
\text { Connolly }\end{array}$ & 20 & Low & $\begin{array}{l}\text { Unemployed (on } \\
\text { youth scheme) }\end{array}$ & $\begin{array}{l}\text { Low level of family support from } \\
\text { mother who is a lone parent. }\end{array}$ \\
\hline $\begin{array}{l}\text { Raymond } \\
\text { Kelly }\end{array}$ & 20 & Low & $\begin{array}{l}\text { Unemployed (on } \\
\text { youth scheme) }\end{array}$ & $\begin{array}{l}\text { Low level of family support. Raised by } \\
\text { mother who is lone parent. }\end{array}$ \\
\hline $\begin{array}{l}\text { Rosalind } \\
\text { Keeling }\end{array}$ & 28 & Low & Disability Benefit & $\begin{array}{l}\text { Middle-class background, but now } \\
\text { living in poverty through lone } \\
\text { parenthood of two children. }\end{array}$ \\
\hline $\begin{array}{l}\text { Majella } \\
\text { Carey }\end{array}$ & 32 & Low & $\begin{array}{l}\text { Public Sector Worker } \\
\text { (on low pay) }\end{array}$ & $\begin{array}{c}\text { Family background working class, no } \\
\text { children but provides care to parents } \\
\text { and siblings. }\end{array}$ \\
\hline Gary Hogan & 36 & Low & Unemployed & $\begin{array}{l}\text { Wife is supporting him while he returns } \\
\text { to education. }\end{array}$ \\
\hline $\begin{array}{l}\text { Glen } \\
\text { Giddens }\end{array}$ & 45 & Low & $\begin{array}{l}\text { Unemployed (on } \\
\text { community } \\
\text { employment scheme) }\end{array}$ & $\begin{array}{l}\text { Divorced father of two. Low socio- } \\
\text { economic status due to divorce and } \\
\text { joblessness. }\end{array}$ \\
\hline Eilis Lynott & 56 & Low & Disability Benefit & $\begin{array}{c}\text { Divorced mother of four adult children, } \\
\text { one of whom has a serious addiction } \\
\text { problem. }\end{array}$ \\
\hline Matt Coyne & 70 & High & Pensioner & $\begin{array}{l}\text { Father of four adult children, two of } \\
\text { whom he is supporting financially. }\end{array}$ \\
\hline $\begin{array}{l}\text { Sylvia } \\
\text { White }\end{array}$ & 83 & High & Pensioner & $\begin{array}{l}\text { Widowed mother of four adult children, } \\
\text { two of whom live abroad. }\end{array}$ \\
\hline $\begin{array}{l}\text { Peggy } \\
\text { O’Carroll }\end{array}$ & 83 & Low & Pensioner & $\begin{array}{l}\text { Widowed mother of one adult child, } \\
\text { some grandchildren abroad and others } \\
\text { planning to emigrate. }\end{array}$ \\
\hline $\begin{array}{l}\text { Patricia } \\
\text { Kilburn }\end{array}$ & 90 & Low & Pensioner & $\begin{array}{l}\text { Widowed mother of two adult children, } \\
\text { both of whom live abroad. }\end{array}$ \\
\hline
\end{tabular}


Figure 1: Participants' Responses to Austerity by Age Group and Socio-economic Status

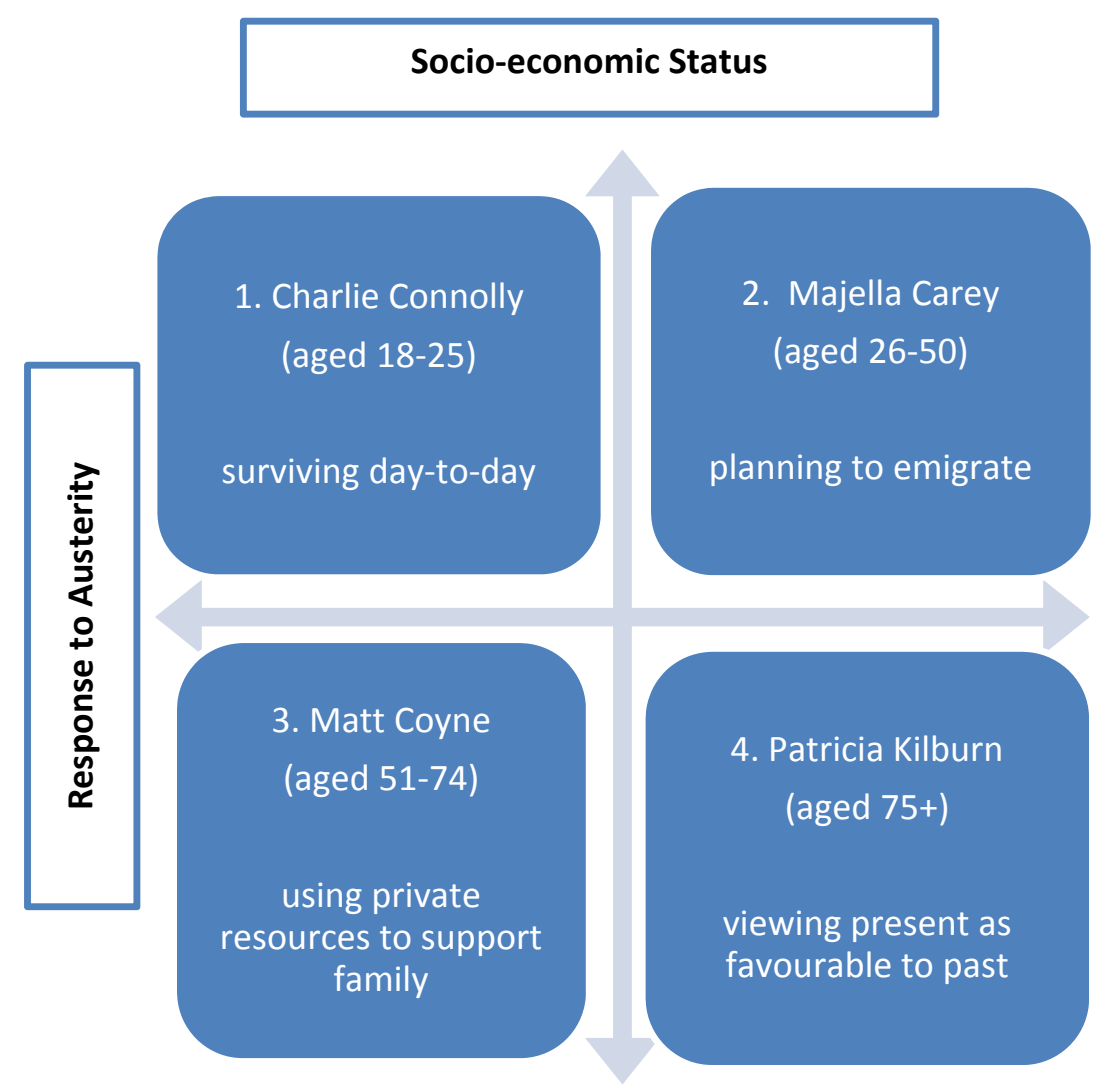

